Int. J. Morphol.,

33(2):725-731, 2015

\title{
The Effect of Dietary Supplements on Healing of Alloplastic Bone Grafted Defects in Rat Tibia
}

\author{
Efecto de los Suplementos Dietarios sobre la Cicatrización de \\ Defectos Injertados con Hueso Aloplástico en la Tibia de Ratas
}

Kaya, A. ; Aktas, A."*; Akdemir, M. F. ${ }^{* * *}$; Kaya, B. . \& Deveci, E.**

KAYA, A.; AKTAS, A.; AKDEMIR, M. F.; KAYA, B. \& DEVECI, E. The effect of dietary supplements on healing of alloplastic bone grafted defects in rat tibia. Int. J. Morphol., 33(2):725-731, 2015.

SUMMARY: The aim of this investigation was to evaluate the potential effects of the systemically delivered combination of calcium, zinc and vit-d supplementation of the locally applied alloplastic bone graft. 28 male Wistar albino rats were used in this study. In each animal, bone defects (10 mm length $¥ 3 \mathrm{~mm}$ width $¥ 2 \mathrm{~mm}$ depth) were created in the tibias. The animals were divided into four groups. In Group 1 (Control Group) rats were fed with standard rat diet. In Group 2 (Calcium Group) rats received calcium carbonate (15 $\mathrm{mg} / \mathrm{kg}$ body weight) suspended in saline. In Group 3 (Calcium/Zinc Group) rats received calcium carbonate (15 mg/kg body weight) and zinc sulfate (4 mg/kg body weight) suspended in saline. In Group 4 (Calcium/Vitamin D Group) rats received calcium carbonate (15 mg/ $\mathrm{kg}$ body weight) and Vitamin D (500 IU/kg body weight) suspended in olive oil. Histopathological analysis of samples was performed to evaluate the process of osteoblastic activity, matrix formation, trabecular bone formation and myeloid tissue in bone defects. Total amounts of osteoblastic activity, matrix formation, trabecular bone formation and myeloid yissue in Ca Group ( $\mathrm{p}=0.002)$, Ca/Zinc Group ( $\mathrm{p}=0.002$ ), and Ca/Vit.D Group ( $\mathrm{p}=0.001$ ) were significantly higher than in Control Group. The total amounts of Ca/Vit.D Group were significantly different than Control Group and $\mathrm{Ca}$ Group. The results of the present study indicated that the oral calcium carbonate supplementation combination with zinc may have systemic effects on accelerating bone regeneration in alloplastic bone grafted tibial defects. Further human studies involving long-term follow up and different type of bone grafts should be conducted.

KEY WORDS: Dietary supplements; Bone healing; Bone grafted; Bone defects; Tibial defects; Alloplastic bone.

\section{INTRODUCTION}

Bone is composed of two main structural types: primary bone and lamellar (secondary) bone (Burkitt et al., 1994). Bone repair process may take months or years (Schilling et al., 1998). The recovery of hard tissues lost during the treatment of pathological processes and traumatic lesions have been extensively studied, and different approaches have been suggested. Autogenous bone graft is considered to be the gold standard for replacement of lost tissue (Puricelli \& Chem, 1985). Advancements in surgical techniques to collect human bone for autogenous grafting are not able to keep pace with the evolution in the production of synthetic materials, such as calcium phosphate cements which have been successfully used for bone repair in the last decade (Kurashina et al., 1998). Bone healing involves complex processes of cell and tissue proliferation and differentiation. Many players are involved, including growth factors, inflammatory cytokines, antioxidants, bone breakdown (osteoclast) and bone building (osteoblast) cells, hormones, amino acids, and uncounted nutrients (Marsh \& $\mathrm{Li}, 1999)$. Calcium (Ca) is an essential nutrient for normal growth and development. Adequate dietary calcium builds the skeleton and helps to prevent skeletal disorders during childhood and adolescence (Matkovic et al., 1991). The main minerals in bone are calcium and phosphorus, in the form of calcium hydroxyapatite (HA) crystals. This HA compound plays an important role in regulating the elastic stiffness and tensile strength of bone (Sims, ek et al., 2006). The building and rebuilding of bone tissue requires adequate supplies of both calcium and phosphorus, which can be supplied from diet and bone reserves. Early research suggested that bone fractures can heal normally independent of dietary calcium and indeed it has been found that during the first few weeks

* Dicle University Dentistry Faculty Department of Oral and Maxillofacial Surgery, Diyarbakır, Turkey.

** Dicle University Medicine Faculty Department of Histology and Embryology, Diyarbakır, Turkey.

**** Inönü University Faculty of Fisheries, Malatya, Turkey. 
of healing, calcium is drawn from the skeleton for bone healing. Inadequate dietary calcium during the critical growth and building period may result in failure to reach peak bone mass (Key \& Odell, 1955). Vitamin-D (Vit. D) is the primary regulator of calcium absorption and without adequate Vit. D calcium blood level drops making less calcium available for fracture healing. Further, we now know that vitamin D, in conjunction with vitamin $\mathrm{K}$, stimulates the transformation of fracture site stem cells to bone building osteoblasts (Steier et al., 1967). Zinc has an important role in osteogenesis. Bone has one of the highest concentrations of zinc of all tissues. Several zinc-dependent enzymes and hormones are involved in bone metabolism. One of them is stimulation of the activity of alkaline phosphatase (ALP), which is involved in bone mineral deposition. The cellular mechanism of zinc action has been demonstrated to stimulate proliferation and differentiation in osteoblastic cells and to inhibit formation of osteoclastic cells. It causes the decrease of cellular zinc content and protein synthesis in bone tissues (Yamaguchi \& Yamaguchi, 1986). The aim of this study was to investigate the effects of dietary calcium with zinc and Vit. D supplements in the healing of calcium phosphate bone grafted tibial defects in rat model.

\section{MATERIAL AND METHOD}

This research was conducted with the approval of the Dicle University Animal Care and Use Ethical Committee (permit no: 2011-31) and rats were purchased from the Dicle University Center of Experimental Medical Research. Twenty-eight male Wistar albino rats weighting 200-215 g were used in this study. Rats were housed in standard cages at a temperature $\left(22 \pm 2{ }^{\circ} \mathrm{C}\right)$ and humidity $(55 \pm 5 \%)$ controlled room that maintained with a $12 / 12 \mathrm{~h}$ light/dark cycle throughout the experiment. The animals consumed a commercial standard laboratory diet and tap water ad libitum. The animals were anesthetized by intraperitoneal injection $5 \mathrm{mg} / \mathrm{kg}$ of Ketamine (Ketalar®, Eczacıbas, 1 , Turkey) and Xylazine HCL (Rompun ${ }^{\circledR}$, Bayer, Turkey). The skin was shaved and scrubbed with an antiseptic solution (1\% iodine). A $2 \mathrm{~cm}$ longitudinal incision was made along the frontal aspect of tibia and flaps were raised to expose the bone tissue. Ten millimeters long, $3 \mathrm{~mm}$ deep and $2 \mathrm{~mm}$ wide circular standard bone defects involving cortical and cancellous bone layers were performed by round dental bur with low rpm, under irrigation sterile saline and suction. The defects were filled with the alloplastic bone graft (Beta Tricalcium Phosphate (b-TCP) Suprabone ${ }^{\circledR}, 1-2 \mathrm{~mm}$ particle size, BMT Calsis, Turkey) graft material. The periosteum was closed using silk 3-0 sutures (Ethicon®, Edinburgh, UK). Rats were divided into four experimental groups. Calcium
Carbonate (CaCO3) (Calcium Sandoz Forte ${ }^{\circledR}$, Novartis, Turkey), Zinc Sulfate (Zinco ${ }^{\circledR} 15 \mathrm{mg}$, Berko, Turkey) and Vitamin D (Devit-3, Deva, Turkey) were administered intragastrically one time per day during the experimental period (Fig. 1).

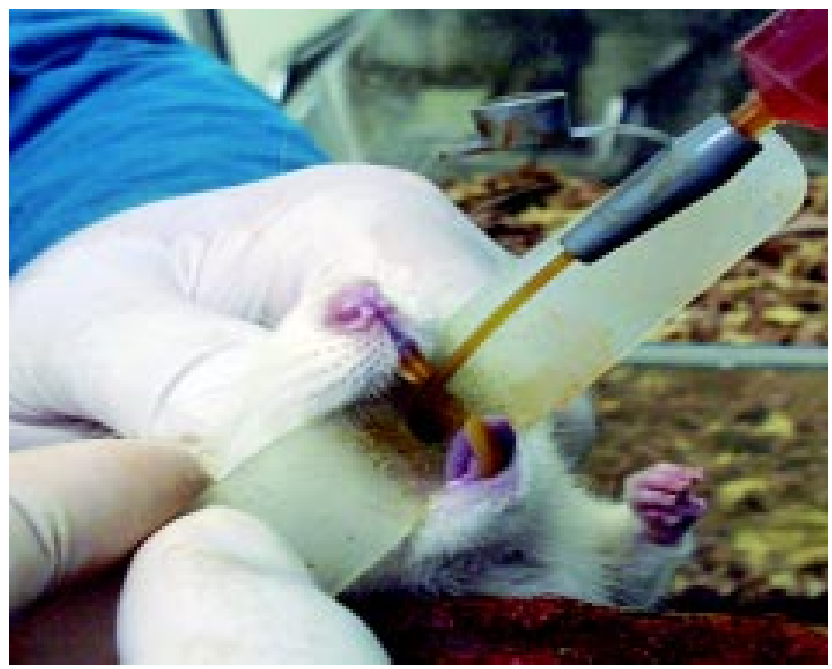

Fig. 1. Intragastrically supplement administration.

Group 1: Rats were fed with standard rat diet.

Group 2: Rats received $\mathrm{CaCO}_{3}(15 \mathrm{mg} / \mathrm{kg})$ suspended in saline. Group 3: Rats received $\mathrm{CaCO}_{3}(15 \mathrm{mg} / \mathrm{kg})$ and Zinc Sulfate $(4 \mathrm{mg} /$ $\mathrm{kg}$ ) suspended in saline.

Group 4: Rats received $\mathrm{CaCO}_{3}(15 \mathrm{mg} / \mathrm{kg})$ and Vitamin D (500 IU/ $\mathrm{kg}$ ) suspended in olive oil.

The rats were sacrified by an overdose of sodium thiopental (Pentothal ${ }^{\circledR}$ ) to assess the bone healing response on the 21st postoperative day. A skin incision with a periosteal flap was used to expose the tibial bone and the previously grafted site was excised widely. The samples were fixed in $10 \%$ buffered neutral formalin for $24 \mathrm{~h}$ and then decalcified in a formic acid-hydrochloride acid combination for $24 \mathrm{~h}$. After rinsing with tap water, the samples were dehydrated in increasing concentrations of ethanol and embedded in paraffin. Tissue sections of 5-7 mm thickness were prepared in the transverse plane and stained using Hematoxylin-eosin and Masson's trichrome staining methods.

The data were analyzed statistically using the Statistical Package for the Social Sciences, ver.12.0 (SPSS, Chicago, IL, USA). The results are expressed as means \pm standard deviation (SD). Differences were evaluated using the Mann-Whitney U-test, and p values <0.05 were considered to indicate statistical significance. 


\section{RESULTS}

The histological characteristics of each surgical bone cavity within each group are described. The bone regeneration process were evaluated to pattern on the grade of osteoblastic activity, matrix formation, trabecular bone formation and myeloid tissue (Tables I and II).

Closure of the defect areas were seen acceleration of the stem cell formation could be seen by increasing of the myeloid tissue and reticular fiber activity and also increased new lamellar bone formation was observed according to maturation of the bone matrix by osteoblasts. Increased osteoblastic activity was found between spongeous and trabecular bone tissues (Fig. 2). Low osteoblastic activity was evidenced by poor osteoblasts and osteosits lining periferarly of the trabecular bone. Additionally myeloid tissue formation in bone narrow was higher more thanmatrix and trabecular bone formation (Fig. 3). Despite the presence of new trabecular bone formation and matrix formation, bone

Table I. Histopathological values of the each subject.

\begin{tabular}{|c|c|c|c|c|c|}
\hline & $\begin{array}{c}\text { Osteoblastic } \\
\text { activity }\end{array}$ & $\begin{array}{c}\text { Matrix } \\
\text { formation }\end{array}$ & $\begin{array}{c}\text { Trabecular } \\
\text { bone formation }\end{array}$ & $\begin{array}{c}\text { Myeloid } \\
\text { tissue }\end{array}$ & Total \\
\hline Group 1-Subject-1 & 1 & 1 & 1 & 1 & 4 \\
\hline Group 1-Subject-2 & 1 & 1 & 0 & 2 & 4 \\
\hline Group 1-Subject-3 & 1 & 2 & 1 & 2 & 6 \\
\hline Group 1-Subject-4 & 1 & 1 & 1 & 2 & 3 \\
\hline Group 1-Subject-5 & 2 & 1 & 1 & 2 & 6 \\
\hline Group 1-Subject-6 & 1 & 1 & 1 & 2 & 5 \\
\hline Group 1-Subject-7 & 1 & 1 & 1 & 2 & 5 \\
\hline Group 2-Subject-1 & 2 & 2 & 3 & 3 & 10 \\
\hline Group 2-Subject-2 & 2 & 2 & 2 & 2 & 8 \\
\hline Group 2-Subject-3 & 2 & 2 & 3 & 2 & 9 \\
\hline Group 2-Subject-4 & 1 & 1 & 3 & 3 & 8 \\
\hline Group 2-Subject-5 & 2 & 2 & 3 & 3 & 10 \\
\hline Group 2-Subject-6 & 1 & 2 & 3 & 3 & 9 \\
\hline Group 2-Subject-7 & 2 & 2 & 3 & 3 & 10 \\
\hline Group 3-Subject-1 & 3 & 2 & 3 & 3 & 11 \\
\hline Group 3-Subject-2 & 3 & 3 & 3 & 3 & 12 \\
\hline Group 3-Subject-3 & 2 & 3 & 2 & 3 & 10 \\
\hline Group 3-Subject-4 & 3 & 3 & 3 & 3 & 12 \\
\hline Group 3-Subject-5 & 2 & 3 & 3 & 3 & 11 \\
\hline Group 3-Subject-6 & 2 & 2 & 3 & 3 & 10 \\
\hline Group 3-Subject-7 & 3 & 3 & 3 & 3 & 12 \\
\hline Group 4-Subject-1 & 2 & 3 & 2 & 3 & 10 \\
\hline Group 4-Subject-2 & 2 & 2 & 2 & 3 & 9 \\
\hline Group 4-Subject-3 & 2 & 3 & 2 & 3 & 10 \\
\hline Group 4-Subject-4 & 2 & 3 & 2 & 3 & 10 \\
\hline Group 4-Subject-5 & 3 & 3 & 3 & 3 & 12 \\
\hline Group 4-Subject-6 & 2 & 3 & 2 & 3 & 10 \\
\hline Group 4-Subject-7 & 2 & 3 & 2 & 3 & 10 \\
\hline
\end{tabular}

Scoring system $0=$ None, $1=$ Low, $2=$ Moderate, $3=$ High.

Table II. Histopathological values of the groups.

\begin{tabular}{cccccc}
\hline & $\begin{array}{c}\text { Osteoblastic } \\
\text { activity }\end{array}$ & $\begin{array}{c}\text { Matrix } \\
\text { formation }\end{array}$ & $\begin{array}{c}\text { Trabecular bone } \\
\text { formation }\end{array}$ & $\begin{array}{c}\text { Myeloid } \\
\text { tissue }\end{array}$ & Total \\
\hline Group 1 & 8 & 8 & 6 & 13 & 35 \\
Group 2 & 12 & 13 & 20 & 24 & 69 \\
Group 3 & 18 & 19 & 20 & 21 & 78 \\
Gorup 4 & 15 & 20 & 15 & 21 & 71 \\
\hline
\end{tabular}




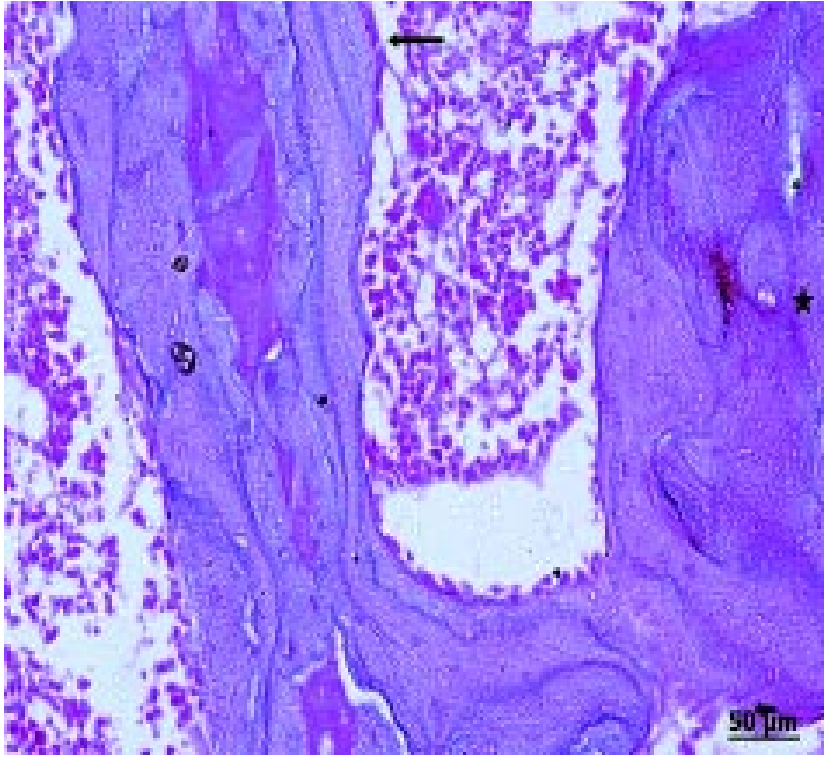

Fig. 2. Osteoblastic activity (Arrow), Haversian lamells (*) (Hematoxylin and Eosin, bar $=50 \mu \mathrm{m}$ ).

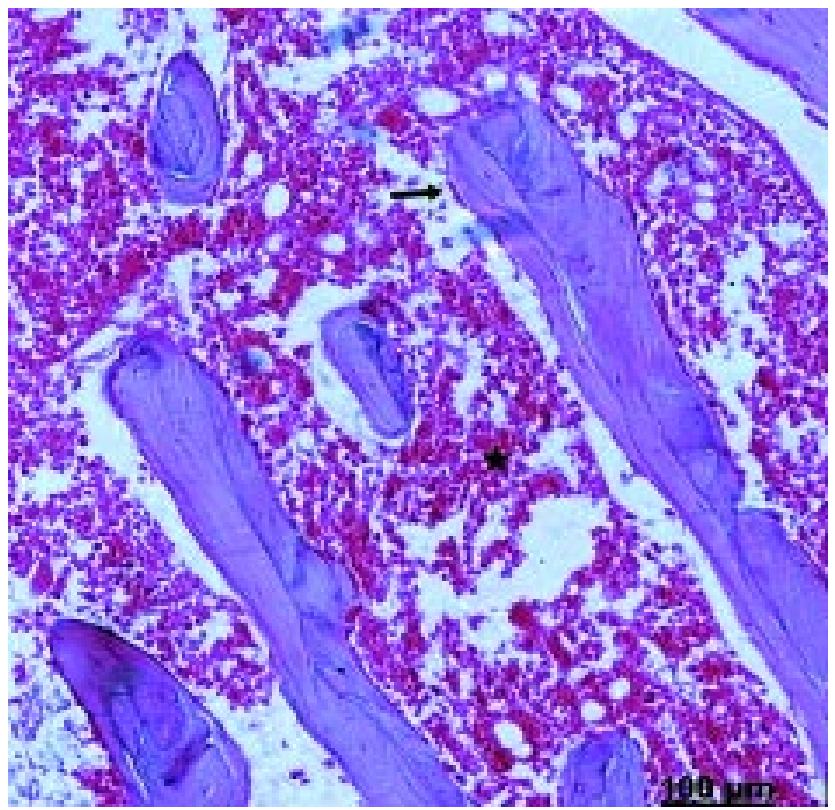

Fig. 3. Flat the osteoblast cells (Arrow), Myeloid tissues (*) (Hematoxylin and Eosin, bar $=100 \mu \mathrm{m}$ ).

healing was not significant. Osteoblasts were lining as cubical between spongeous and trabecular bone tissues. Nevertheless increased lipid cell formation and myeloid tissue formation were observered with increased mitotic activity in the myeloid tissue. There were also some small vessels in the trabecular bone with increased osteocytic activity (Fig. 4). The samples in this group showed increased bone lamellae formation in the trabecular bone and increased osteoblastic activity in the lacunar area. Matrix formation

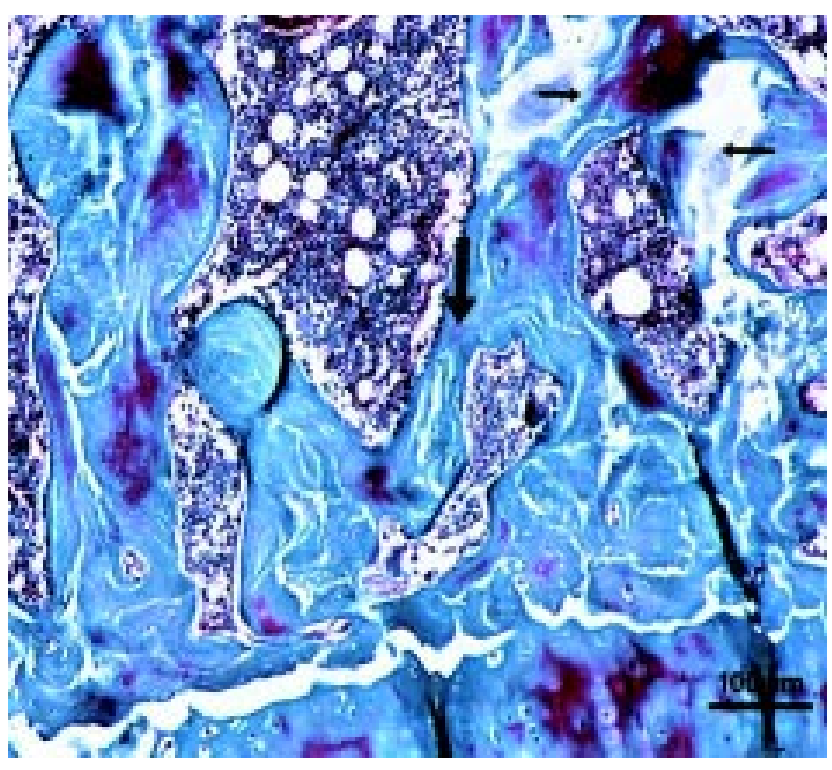

Fig. 4. Bone loss in the defect area (Thin arrow), cubical osteoblast cells and Matrix formation (bold arrow) (Masson's trichome, Bar= $100 \mu \mathrm{m})$

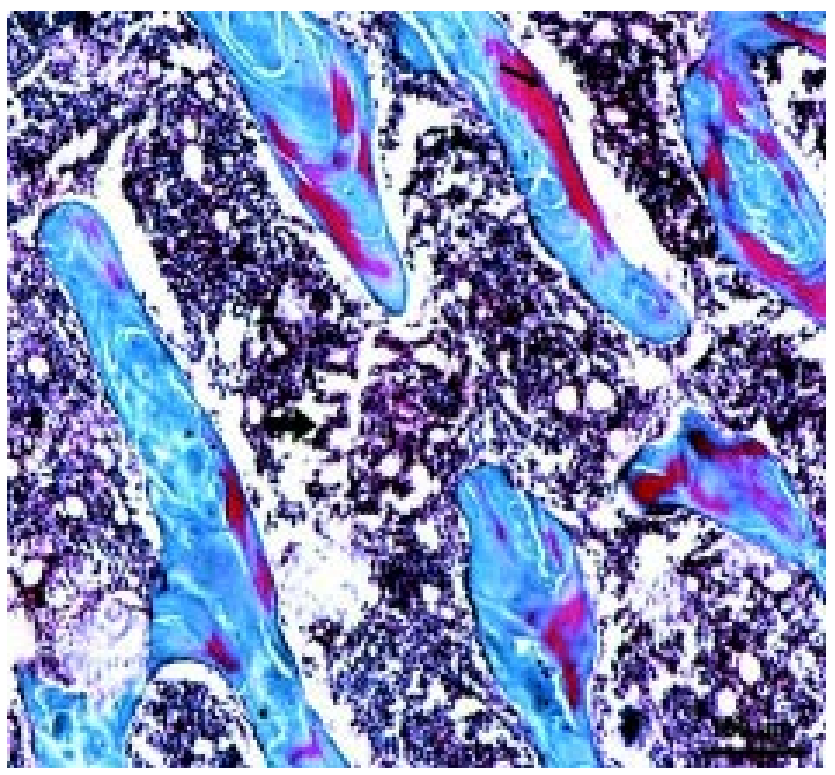

Fig. 5. Trabecular matrix (Thin arrow), lipid cells (bold arrow) (Masson's trichome, Bar= $100 \mu \mathrm{m}$ ).

and osteoblastic activity were seen strongly significant in the osteoid region (Fig. 5).

Total amounts of Osteoblastic Activity, Matrix Formation, Trabecular Bone Formation and Myeloid Tissue in Group 2 ( $\mathrm{p}=0.002)$, Group 3 ( $\mathrm{p}=0.002)$, and Group $4(\mathrm{p}=$ 0.001 ) were significantly higher than in Group 1 (Control Group). The values of Group 3 and Group 4 were higher than Group 2 but not statistically significant (Table III). 
Table III. Mann-Whitney U-test (p values).

\begin{tabular}{lccccc}
\hline & $\begin{array}{c}\text { Osteoblastic } \\
\text { activity }\end{array}$ & $\begin{array}{c}\text { Matrix } \\
\text { formation }\end{array}$ & $\begin{array}{c}\text { Trabecular } \\
\text { bone formation }\end{array}$ & $\begin{array}{c}\text { Myeloid } \\
\text { tissue }\end{array}$ & Total \\
\hline Group 1 $\rightarrow$ Group 2 & $0.037^{*}$ & 0.010 & $0.001^{*}$ & $0.007^{*}$ & $0.002^{*}$ \\
Group $1 \rightarrow$ Group 3 & $0.002^{*}$ & $0.001^{*}$ & $0.001^{*}$ & $<0.001^{*}$ & $0.002^{*}$ \\
Group $1 \rightarrow$ Group 4 & $0.002^{*}$ & $0.001^{*}$ & $0.001^{*}$ & $<0.001^{*}$ & $0.001^{*}$ \\
Group 2 $\rightarrow$ Group 3 & $0.015^{*}$ & $0.007^{*}$ & 1.000 & 0.141 & $0.005^{*}$ \\
Group 2 $\rightarrow$ Group 4 & 0.091 & $0.002^{*}$ & $0.010^{*}$ & 0.141 & 0.064 \\
Group 3 $\rightarrow$ Group 4 & 0.107 & 0.530 & $0.010^{*}$ & 1.0 & 0.053 \\
\hline
\end{tabular}

$*=p<0.05$ indicates a significant difference.

The total amounts of Group 3 were significantly different than Group 1 and Group 2. No statistical differences were observed in total amounts of Osteoblastic Activity, Matrix Formation, Trabecular Bone Formation and Myeloid Tissue between Group 3 and Group 4. The Trabecular Bone Formation amounts in Group 4 were found less than in Groups 2 and 3 and it was statistically significant $(\mathrm{p}=0.01)$, but Osteoblastic Activity values were not significantly different. The distributions of the histological scores are shown in Figure 6.

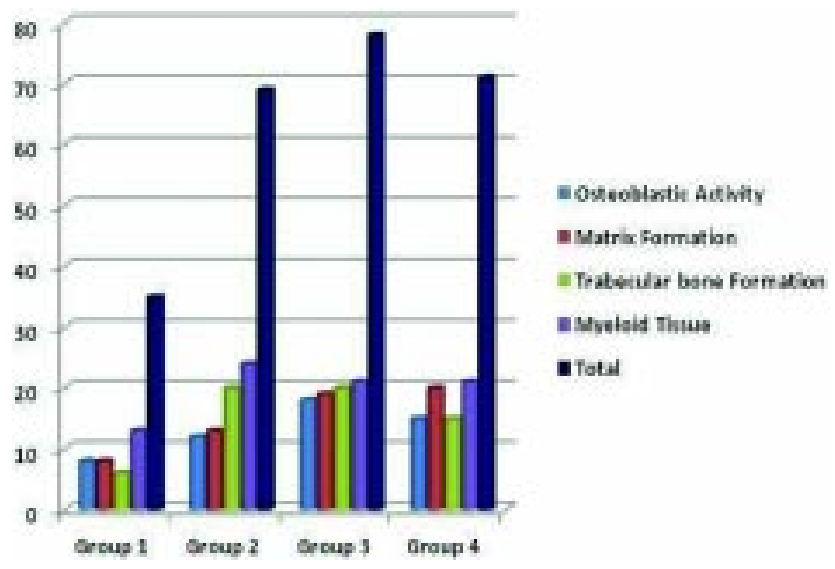

Fig. 6. Schematic summary of results. This diagram shows the median scores.

\section{DISCUSSION}

Calcium supplements are becoming an important source of dietary calcium and a basic defense against osteopenia. Oral calcium supplement is a very popular method of maintenance inadequate dietary calcium because of its cheap cost, convenient way of intake, and the minimal side effects. Generally, calcium supplementation is recognized as accelerating bone formation with less inhibition of bone resorption (Recker, 1993). The role of calcium-regulating hormones, vitamin $\mathrm{D}$, parathyroid hormone and calcitonin, and ions such as calcium and phosphate in mediating osteoinduction is not known. There is evidence that vitamin $\mathrm{D}$ deficiency results in abnormalities in skeletal growth, remodeling, and mineralization. Human studies, in fact, suggest that for best fracture healing both calcium and vitamin D should be obtained in optimum daily levels. Most of us consume plenty of phosphorus and often too much if the diet is high in processed foods and colas. However, the elderly, dieters, and those on low protein diets often do not consume enough phosphorus to meet the needs of new bone formation (Heaney \& Nordin, 2002). Thus we evaluated in this study the efficacy of dietary Calcium supplementation with/without Zinc and Vit-D in healing of the alloplastic bone grafted rat tibial defects.

Hong et al. (2012) evaluated the effects of the oral calcium and cholecalciferol combination (Vit. D/Ca) supplementation and of the locally applied biphasic calcium alloplast on alveolar sockets at the early healing stage in a dog model. The Vit. D/Ca-treated subjects revealed significantly more new bone formation $(\mathrm{P}<0.05)$, higher bone density $(\mathrm{P}<0.05)$ and significantly less vertical ridge reduction $(\mathrm{P}<0.05)$ in the healing sockets than those without Vit. D/Ca treatment. At an early stage of the defect region, results of this study demonstrated that taking calcium supplementation significantly stimulates bone regeneration and better new bone formation than non-supplemented group. The information supports the idea that systemic application of Vit.D/Ca may encourage an early bone healing in investigational areas for the tested animals. Shuid et al. (2010) carried out in a study on the effects of calcium supplementation in the late phase healing of fractured osteoporotic bone using an ovariectomized rat model. They concluded that calcium supplements may appear to improve fracture healing of osteoporotic bone but failed to improve strength. Qin et al. (1998), evaluated in their study the effect of the mixture of calcium carbonate and calcium citrate, on the mandibular alveolar bone debilitation of pubertal rats. They concluded that the mixture of calcium carbonate and calcium citrate had a positive effect on bone debilitation to a certain extent in growth-period rats. Turner et al. (1988), 
implanted demineralized allogeneic bone matrix (DABM) from vitamin $\mathrm{D}$-deficient rats (-D rats) into normal rats $(+\mathrm{D}$ rats). Bone formation $(\mathrm{P}<0.01)$ and total implant mineralization $(\mathrm{P}<0.001)$ were significantly reduced in implants from -D rats, and the reductions corresponded with a decline in the number of osteoblasts $(\mathrm{P}<0.05)$.

In the present study between the Calcium Group (1500 mg CaCO3+400IU Vit.D/kg) and Ca/Vit.D Group (1500 mg CaCO3+400IU Vit.D/kg and $500 \mathrm{IU}$ Vit.D/kg) no significant differences were seen in bone healing. It shows that sparingly Vit. D is enough for intestinal calcium absorption. Calhoun et al. (1975), indicated that dietary zinc deficiency caused a retardation of ectopic bone formation and a significant reduction of in situ zinc and calcium concentration. Dietary zinc repletion to zinc-deficient animals restored the zinc concentration in ectopic bone to a level comparable to that of zinc-sufficient animals. Hosea et al. (2004), investigated the effects of dietary zinc deficiency and diet restriction on bone development in growing rats. Rats were fed either a zinc-deficient diet ad libitum ( $<1 \mathrm{mg}$ zinc/kg) or nutritionally complete diet (30 $\mathrm{mg}$ zinc/ $\mathrm{kg}$ ) either ad libitum (CTL) or pair-fed to the intake of the ZD group (DR; diet-restricted) for 3 weeks (deficiency phase) and then all groups were fed the zinc adequate diet ad libitum for 3,7 , or 23 days (repletion phase). Zinc deficiency was associated with a greater impairment in bone development than diet restriction, and both deficiencies limited bone recovery during repletion in growing rats.

According to our observation we can say systemically administration of Zinc or Vit. D with Ca increased the new bone regeneration in grafted rat tibial defects more than $\mathrm{Ca}$ alone supplementation but only Zinc/ Ca group was statistically different $(\mathrm{p}=0.005)$. Igarashi et $a l$, investigated the effect of zinc acexamate $(10.0 \mathrm{mg} \mathrm{Zn} /$ $100 \mathrm{~g}$ ) for $28 \mathrm{~d}$ on fracture healing of the femoral-diaphyseal tissues in rats. Calcium content and alkaline phosphatase activity in the femoral-diaphyseal tissues were significantly decreased in rats with fracture healing. Femoral mineral density in rats with fracture healing was significantly increased by the administration of zinc acexamate. Femoraldiaphyseal zinc content was significantly decreased in rats with fracture healing (Igarashi \& Yamaguchi, 1999). Jones et al. (2010) evaluated whether alimentary zinc supplementation and depletion affect bone healing of calvarial defects implanted with osteopromotive substances in adult rats. Experimentally created bone defects were filled with demineralized bone matrix (DBM), autogenous bone chips, or were left as unfilled controls. The rats were divided into three groups of 20 rats each and received a semi-synthetic diet containing 20,60, or $120 \mathrm{mg}$ zinc $/ \mathrm{kg}$. Defects filled with DBM were significantly stronger and exhibited significantly more new bone formation than defects filled with autogenous bone or unfilled controls. In our study the rats in Group $\mathrm{Ca} / \mathrm{Zinc}$ were fed with $4 \mathrm{mg} / \mathrm{kg}$ Zinc (Zinc Sulfate $(15 \mathrm{mg} \mathrm{Zn} / 100 \mathrm{ml}$ ) for $21 \mathrm{~d}$. The alloplastic bone grafted tibial tissues of $\mathrm{Ca}$ /Zinc Group revealed significantly more new bone formation compared than those Control Group and Ca Group.

In conclusion it has been demonstrated that the oral administration of calcium carbonate is effective in new bone process and Zinc sulfate has a sinergic stimulatory effect with calcium carbonate on healing of experimental created and alloplastic bone grafted tibial defects in rats.

KAYA, A.; AKTAS, A.; AKDEMIR, M. F.; KAYA, B. \& DEVECI, E. Efecto de los suplementos dietarios sobre la cicatrización de defectos injertados con hueso aloplástico en la tibia de ratas. Int. J. Morphol., 33(2):725-731, 2015.

RESUMEN: El objetivo de esta investigación fue evaluar los efectos potenciales de la combinación sistémica de calcio, zinc y vitamina D como suplemento de la aplicación local de un injerto óseo aloplástico. Fueron utilizadas 28 ratas Wistar albinas (machos). En cada animal, se crearon defectos óseos en las tibias (cuyas medidas fueron: $10 \mathrm{~mm}$ de longitud x $3 \mathrm{~mm}$ de ancho x $2 \mathrm{~mm}$ de profundidad). Los animales fueron divididos en cuatro grupos. En el Grupo 1 (control) las ratas fueron alimentadas con una dieta estándar. En el Grupo 2 (grupo de calcio) las ratas recibieron carbonato de calcio $(15 \mathrm{mg} / \mathrm{kg}$ de peso corporal) suspendido en solución salina. En el Grupo 3 (grupo de calcio/zinc) las ratas recibieron carbonato de calcio $(15 \mathrm{mg} / \mathrm{kg}$ de peso corporal) y sulfato de zinc (4 mg/kg de peso corporal) suspendido en solución salina. El Grupo 4 (calcio/vitamina D) recibió carbonato de calcio ( $15 \mathrm{mg} / \mathrm{kg}$ de peso corporal) y vitamina D (500 $\mathrm{UI} / \mathrm{kg}$ de peso corporal) suspendidos en aceite de oliva. Se realizó un análisis histopatológico de las muestras para evaluar el proceso de actividad osteoblástica, formación de la matriz, hueso trabecular y tejido mieloide en defectos óseos. Las cantidades totales de actividad osteoblástica, formación de matriz, de hueso trabecular y tejido mieloide en los grupos Calcio $(\mathrm{p}=0,002), \mathrm{Calcio} / \mathrm{Zinc}(\mathrm{p}=0,002)$, y Calcio/Vitamina $\mathrm{D}(\mathrm{p}=0,001)$ fueron significativamente mayores que en el grupo de control. Las cantidades totales de Calcio/Vitamina D Grupo fueron significativamente diferentes de los grupos Control y Calcio. Los resultados del presente estudio indican que lacombinación de suplementos de carbonato de calcio por vía oral con zinc puede tener efectos sistémicos sobre la aceleración de la regeneración ósea en defectos tibiales con injertos aloplásticos. Deben llevarse a cabo otros estudios en humanos, que involucren un largo plazo de seguimiento y también diferentes tipos de injertos óseos.

PALABRAS CLAVE: Suplementos dietéticos; Cicatrización ósea; Injerto óseo; Defectos óseos; Defectos tibiales; HueSo aloplástico. 


\section{REFERENCES}

Burkitt, H. G.; Young, B.; Heath, J. W. Wheater Histologia Funcional. 3rd ed. Rio de Janeiro, Guanabara Koogan, 1994.

Calhoun, N. R.; Smith, J. C. Jr. \& Becker, K. L. The effects of zinc on ectopic bone formation. Oral Surg. Oral Med. Oral Pathol., 39(5):698-706, 1975.

Heaney, R. P. \& Nordin, B. E. Calcium effects on phosphorus absorption: implications for the prevention and co-therapy of osteoporosis. J. Am. Coll. Nutr., 21(3):239-44, 2002.

Hong, H. H.; Chou, T. A.; Yang, J. C.; \& Chang, C. J. The potential effects of cholecalciferol on bone regeneration in dogs. Clin. Oral Implants Res., 23(10):1187-92, 2012.

Hosea, H. J.; Taylor, C. G.; Wood, T.; Mollard, R. \& Weiler, H. A. Zinc-deficient rats have more limited bone recovery during repletion than diet-restricted rats. Exp. Biol. Med. (Maywood), 229(4):303-11, 2004.

Igarashi, A. \& Yamaguchi, M. Stimulatory effect of zinc acexamate administration on fracture healing of the femoral-diaphyseal tissues in rats. Gen. Pharmacol., 32(4):463-9, 1999.

Jones, L.; Thomsen, J. S.; Barlach, J.; Mosekilde, L. \& Melsen, B. No influence of alimentary zinc on the healing of calvarial defects filled with osteopromotive substances in rats. Eur. $J$. Orthod., 32(2):124-30, 2010.

Key, J. A. \& Odell, R. T. Failure of excess minerals in the diet to accelerate the healing of experimental fractures. J. Bone Joint Surg. Am., 37-A(1):37-44, 1955.

Kurashina, K.; Kurita, H.; Kotani, A.; Kobayashi, S.; Kyoshima, K. \& Hirano, M. Experimental cranioplasty and skeletal augmentation using an alpha-tricalcium phosphate/dicalcium phosphate dibasic/tetracalcium phosphate monoxide cement: a preliminary short-term experiment in rabbits. Biomaterials, 19(7-9):701-6, 1998.

Marsh, D. R. \& Li, G. The biology of fracture healing: optimising outcome. Br. Med. Bull., 55(4):856-69, 1999.

Matkovic, V. Calcium metabolism and calcium requirements during skeletal modeling and consolidation of bone mass. Am. J. Clin. Nutr., 54(1 Suppl.):245S-260S, 1991.

Puricelli, E. \& Chem, R. C. Reconstrução de mandíbula com fíbula. Rev. Gaúcha Odontol., 33:124-7, 1985.

Qin, M.; Zhang, Z.; Maki, K.; Naito, M.; Morimoto, A. \& Kimura, $M$. The effect of calcium supplement given with a mixture of calcium carbonate and calcium citrate on the mandibular alveolar bone of pubertal rats. J. Bone Miner. Metab., 16(2):8895, 1998.
Recker, R. R. Prevention of osteoporosis: calcium nutrition. Osteoporosis Int., 3 Suppl. 1:163-5, 1993.

Schilling, T.; Müller, M.; Minne, H. W. \& Ziegler, R. Influence of inflammation-mediated osteopenia on the regional acceleratory phenomenon and the systemic acceleratory phenomenon during healing of a bone defect in the rat. Calcif. Tissue Int., 63(2):1606, 1998.

Shuid, A. N.; Mohamad, S.; Mohamed, N.; Fadzilah, F. M.; Mokhtar, S.A.; Abdullah, S.; Othman, F.; Suhaimi, F.; Muhammad, N. \& Soelaiman, I. N. Effects of calcium supplements on fracture healing in a rat osteoporotic model. J. Orthop. Res., 28(12):1651-6, 2010.

Sims sek, A.; Senköylü, A.; Cila, E.; Ug urlu, M.; Bayar, A.; Oztürk, A. M.; Is sikli, S.; Mus dal, Y. \& Yetkin, H. Is there a correlation between severity of trauma and serum trace element levels? Acta Orthop. Traumatol. Turc., 40(2):140-3, 2006.

Steier, A.; Gedalia, I.; Schwarz, A. \& Rodan, A. Effect of vitamin D2 and fluoride on experimental bone fracture healing in rats. J. Dent. Res., 46(4):675-80, 1967.

Turner, R. T.; Farley, J.; Vandersteenhoven, J. J.; Epstein, S.; Bell, N. H. \& Baylink, D. J. Demonstration of reduced mitogenic and osteoinductive activities in demineralized allogeneic bone matrix from vitamin D-deficient rats. J. Clin. Invest., 82(1):212$7,1988$.

Yamaguchi, M. \& Yamaguchi, R. Action of zinc on bone metabolism in rats. Increases in alkaline phosphatase activity and DNA content. Biochem. Pharmacol., 35(5):773-7, 1986.

\author{
Correspondence to: \\ Prof. Engin Deveci \\ Department of Histology and Embryology \\ Medicine Faculty \\ Dicle University \\ Diyarbakır \\ TURKEY
}

Email: engindeveci64@gmail.com

Received: 03-11-2014

Accepted: 09-02-2015 